\title{
Memória individual como expressão de uma memória social: reminiscências reveladoras das múltiplas facetas de Fortaleza
}

\author{
Gisafran Nazareno Mota Jucá*
}

\section{Considerações preliminares}

A História das Cidades nos remete a diferentes fontes e testemunhos, projetada não apenas através de figuras alegóricas que se entrecruzam em múltiplas paisagens, mas estampada na projeçáo de um enredo plural, onde os eventos oficiais e as práticas cotidianas se imbricam de forma polivalente e multifacetada. Por mais numerosas que sejam as fontes disponíveis, oficiais ou oficiosas, há outro acervo, nem sempre valorizado, mais representativo e envolvente, presente na força expressiva da oralidade e/ou no alcance da memória social.

O meu interesse pela História Urbana foi fruto de um acaso circunstancial, quando aluno da primeira turma do Mestrado em História, da Universidade Federal de Pernambuco (UFPE), numa aula prática da disciplina Métodos e Técnicas da Pesquisa Histórica, a cargo do Professor Armando Souto Maior, que deixou à livre escolha dos alunos os temas de uma monografia exigida, como avaliaçáo, do acervo do Arquivo Público de Pernambuco, referente à segunda metade do século XIX. Os alunos do Recife, sem dificuldades fizeram suas escolhas temáticas, mas para quem vinha do Ceará, ainda permanecia vivo o interesse em repensar o tema do pioneirismo da abolição da escravatura, motivo de orgulho e divagaçôes para os filhos da decantada "terra da luz". Uma indagação permanecia viva e me fazia repensar esse pioneirismo: teria sido apenas o idealismo libertador dos abolicionis-

* Professor Aposentado do Departamento de História da Universidade Federal do Ceará (UFC); Professor Titular do Curso de História da Universidade Estadual do Ceará, (UECE); Professor da Pós-Graduação em Educação da UFC; Membro Efetivo do Instituto do Ceará (Histórico, Geográfico e Antropológico). E-mail: gisafranjuca@gmail.com. 
tas locais, sob a ousadia do consagrado "Dragão do Mar" (como ficou conhecido Francisco José do Nascimento), que se recusou a continuar o transporte de escravos dos navios que permaneciam ao largo, em virtude da pouca profundidade das praias locais, até à Ponte Metálica, onde se acumulavam as bagagens e produtos transportados e exportados? A mão de obra escrava constituía o suporte básico das atividades agrárias na acanhada Província de Fortaleza, sempre a reboque de outros grandes centros comerciais da região, como Pernambuco e Salvador?

A resposta a essas indagaçóes foram respondidas por outro pesquisador, uma vez que as circunstâncias me fizeram aceitar a sugestâo de me dedicar ao estudo das "Companhias Urbanas do Recife", na segunda metade do Século XIX. Dos três tomos documentais sobre as mesmas, me foi indicada as fontes manuscritas e impressas sobre A Companhia do Beberibe, responsável pela implantação do sistema de abastecimento de água do Recife e, a princípio, me senti perdido ante essa opção imposta: como o histórico de uma companhia dedicada a um serviço básico poderia me levar à compreensão da história regional? No decorrer do fichamento da documentação disponível, fui percebendo o sentido revelador dos serviços urbanos, que se projetavam como a base do atendimento aos desafios da urbanização. Com a orientação de um professor americano, eu pude perceber o significado e o alcance da História Urbana como pano de fundo do cenário tradicional da História, ainda limitado à História Política como campo prioritário das pesquisas em andamento. A tradição desse campo se afigurava como uma demonstração convincente da persistência da força do legado historiográfico positivista no meio cultural e universitário.

A projeção do Recife na rede urbana regional me levou a novas indagações sobre a História Urbana Regional e suas possibilidades metodológicas, e assim, a temática da minha tese de doutorado representou uma continuidade da pesquisa de mestrado e o viés da História Comparada me permitiu mergulhar mais fundo na História Urbana Regional.

À primeira vista, esses três parágrafos rememorativos da minha formação acadêmica, podem parecerem digressivos, mas os considero como uma expressão probatória do alcance da História Urbana, revelado pela multiplicidade de fontes e de opçôes metodológicas geradoras de estudos transdisciplinares (Japiassu, 2006), onde o historiador é apenas um narrador a mais ante a pluralidade de temas e de pesquisadores de outras áreas, como a Geografia, a Sociologia, a Economia, a Arquitetura, que nos fazem ultrapassar as estreitas e contraditórias fronteiras tradicionais, ainda indicadas no rol das exigências mais impostas do que propostas aos profissionais da História.

A busca de mais informes me levou a outras fontes além das tradicionalmente indicadas e, em termos de novas perspectivas metodológicas, ao uso da História Oral, a princípio concebida como uma técnica complementar. Isso me 
levou a refazer minha limitada visão, ao descobrir o sentido inovador da pesquisa urbana quando embasada na conexão contínua entre a representação da memória individual e da memória coletiva (Halbwachs, 1990), também definida como memória social (Fentress; Wickham,1994), quando a realidade concreta se projeta no imaginário e nas revelaçôes oriundas da subjetividade colocadas nos depoimentos coletados, cujos autores levam o pesquisador a romper seu limitado monólogo, transformando-o em um diálogo contínuo entre entrevistador e entrevistados. Assim, o que parecia uma simples coleta de informes complementares se transforma em uma prática de pesquisa bem mais abrangente, quando o individual e o social nos remetem a outras configuraçóes oriundas dessa ruptura com a visão tradicional de escolha de temas e fontes a serem analisadas.

A descoberta do valor dos testemunhos vivos da História Urbana, não mais projetada apenas em uma totalidade histórica, mas multifacetada "em migalhas" (Dosse, 1992, traz a lume, além dos grandes vultos e eventos rememorados, as reveladoras práticas cotidianas "nas artes de fazer" (Certeau, 1994), para além dos limites da Arqueologia do Saber, indicada por Michael Foucault. Concretamente, uma razão especial me fez recorrer aos depoimentos de pessoas idosas sobre Fortaleza, cujo valor memorial tem um significado especial, quando velhos narradores revelam novas significaçóes das experiências observadas, uma vez que eles não têm receio de expor suas ideias (Jucá, 2003).

Eles são personagens históricos mais livres, sem pátria nem patrão, portadores de um senso crítico mais aguçado e isento das imposiçóes avaliativas generalizantes tão comuns nos ditames e práticas cotidianas da globalização.

\section{O Reconhecimento de um mestre, como guia, no labirinto das trilhas urbanas}

A princípio, pensei nos critérios de escolha de um ambiente propício à coleta de informaçóes, de um depoente na terceira idade que pudesse evitar o barulho cotidiano de uma residência, sempre repleta de filhos e/ou netos, ao mais das vezes presentes temporariamente, porque cada um tem seus compromissos e obrigaçóes cotidianas, mas uma vez que a maioria deles reside no mesmo bairro, a visita de passagem cotidiana faz parte da agenda espontânea de cada um deles.

Quando lhe indaguei, onde achava mais conveniente o ambiente de privacidade, ele fez a seguinte advertência:

Se você quer obter um depoimento espontâneo, sem formalidade, me acompanhe no percurso que faremos pelas ruas da cidade e assim o cruza- 
mento de ruas e subjetividades se revelarão como um espelho da cidade, não um espelho requintado, típico de ambientes sociais específicos, mas um espelho sem moldura fixa, com partes límpidas e florescentes e outras trincadas ou estilhaçadas, afinal a pluralidade de paisagens naturais e sociais nos permitem divisar o perfil urbano de uma capital como Fortaleza, onde o ontem e o hoje continuam entrelaçados, apesar da maioria das pessoas, que nela vive, não percebem o significado das representações estampadas nos diferentes espaços observados. (Francisco José de Castro Oliveira, 2018).

Assim, numa manhã de sábado ensolarada, nos encontramos na Praça do Ferreira, ponto central da capital cearense. A primeira observação, por ele apresentada, foi relativa à paisagem natural assim configurada:

Qualquer paisagem e, em especial, uma paisagem urbana, pode ser visualizada de forma mecânica, num abrir e fechar de olhos, mas não é a melhor opção para contemplar o que nos cerca. O panorama projetado, ante nosso poder de percepção, depende de algo a mais, bem interior, do estado de espírito do "voyeur," capaz de alterar a tonalidade do cenário reproduzido, em cores claras ou obscuras, afinal o real e o imaginário sempre se mesclam, seja em nossos sonhos, seja na nossa visão cotidiana, direcionada a um algo escolhido ou imposto pelas circunstâncias. Pela tradição bairrista local, o Ceará foi consagrado, como "Terra da Luz", por ter sido a primeira Província a abolir a escravatura, mas pra mim essa denominação tem outra origem, bem nítida, em nosso entorno, o sol sempre brilha, mesmo no período chuvoso, quando as chuvas, por mais pesadas que sejam, findam com o renascer do forte brilho do sol. (Francisco José de Castro Oliveira, 2018).

E ele acrescentou ao seu comentário as razões desse pioneirismo abolicionista: o Ceará não representou um campo de produção colonial significativo, sempre atuou como uma economia complementar, desde as trilhas do gado, que deram origem a várias cidades interioranas, em sua maioria, situadas à margem de rios, como o Jaguaribe, o Acaraú ou outros menos significativos, como o Patu e o Banabuiú, mas que tinham um poder de atração aos grupos humanos que se deslocavam, com o impulso do processo criatório, bem analisado por Capistrano de Abreu (1976), ao explicar o porquê da criaçáo do gado, bem distante da zona canavieira, capaz de criar outra atividade produtiva como as charqueadas, fornecedoras da carne de sol, consumida nos distantes engenhos da zona canavieira.

Nessa rota do gado, no Ceará, se projetavam duas cidades, mais antigas 
e mais ativas, como centros de produção e ocupação espacial, mais do que a capital cearense: Icó, no alto sertão, onde se cruzavam as boiadas vindas do interior paraibano e deslocadas em direção ao interior piauiense, que tinha como polo administrativo a antiga capital; e a cidade de Oeiras, que tâo bem nos explica o percurso da ocupação territorial do Piauí, mais abrangente e espacialmente mais largo ao sul e que se estreitava em direção ao norte, deixando a antiga capitania sem ligação direta com o mar, só obtida com a permuta de parte territorial efetuado com o Ceará, que lhe cedeu o espaço litorâneo de Parnaíba em troca da regiáo fronteiriça de Crateús, que se projetaria como outro centro urbano de destaque no interior cearense.

Até a instalação do sistema político administrativo provincial, após a independência do Brasil, mais do que Icó, Aracati se projetara como o principal centro comercial exportador cearense, atraindo inclusive a vinda de comerciantes de origem estrangeira, como franceses de tradição judaica, que instalavam os grandes armazéns de compra e venda de produtos oriundos da Europa.

Após essa significativa explicação acerca das origens da rede urbana local, indaguei de onde retirara o termo "voyeur" e ele logo me respondeu, "acompanhando a caminhada de Walter Benjamin pelas ruas de Paris" (Francisco José de Castro Oliveira, 2018). Esse significativo comentário nos revela o valor da narrativa apresentada por um viajante estrangeiro, encantado com o brilho esfuziante e/ou embotado, dependendo das figuras e configuraçóes, estampadas nas ruas e ruelas de Paris, na primeira metade do século vinte.

$\mathrm{Na}$ época, havia um confronto contínuo entre a visão a alemã e a francesa, em decorrência da disputa constante entre os dois países, que terminaria com a tomada e retomada de regióes simbólicas no mapa europeu, a da Alsácia e a de Lorena. A originalidade maior do olhar arguto de Benjamin se revela na sua percepção inovadora, mesmo que embasada na dialética "marxiana", de enxergar além da consagrada luta de classes, onde sempre o operário se revelava como o agente demolidor do velho modelo social, observando outras paisagens sociais, tão bem reveladas nos espaços urbanos, e outros agentes do processo histórico.

De acordo com o nosso depoente, a primeira vez que ouvira falar do consagrado narrador alemáo, que encantava os leitores de seus textos, teve uma grande decepção, porque esperava encontrar nele um arauto da almejada redenção da classe operária, consciente de seus encargos e obrigaçóes, na luta pela implantação redentora da "ditadura do proletariado", mas o primeiro livro de Benjamin que chegou as suas mãos ("Documentos de cultura, documentos de barbárie", compilação publicada no Brasil em 1986) o deixou "confuso e decepcionado, sem entender qual seria a proposiçáo inovadora e revolucionária desse pensador, uma vez que, se era marxista, logicamente não poderia fugir a uma tentativa de aplicação prática da almejada dialética social” (Francisco José de Castro Oliveira, 2018). 
E aos poucos veio o significado revelador de um novo olhar sobre a realidade social, indo além do eterno conflito entre dominador e dominado, percorrendo o labirinto da política cultural dos diferentes tipos de atividade, onde a tradição e o patrimônio se entrecruzam. A chamada "crítica militante" de Benjamin vai além da crítica literária, onde a compreensão das contradiçôes culturais parte de um polo oposto, a "barbárie".

Nessa perspectiva, a cultura passou a ser compreendida sob um enfoque diferente, uma vez que ela é fruto de confrontos e contestaçóes e náo apenas revelada como o resultado de uma ordem social imposta por uma força diretriz em busca da abertura de uma sociedade sem classes.

Aos poucos ele foi descobrindo o brilho das centelhas que emergiam da análise benjaminiana, que mergulhavam mais a fundo no mar revolto da sociedade europeia do entre guerras, quando ao mais das vezes as visóes culturais ainda se limitavam ao peso do nacionalismo exacerbado, impedindo uma conexão mais significativa entre maneiras de pensar e agir diferenciadas, mas que se entrelaçavam nas práticas sociais cotidianas e nas relaçôes diplomáticas internacionais.

Com o passar do tempo, outras leituras indicadas foram aguçando o seu interesse em aprofundar a análise acerca da contribuição de Benjamin e, nessa trajetória bibliográfica, as contribuiçóes de Konder (1988), Kothe (1976, 1978, 1985), Pernisa Junior et al. (2008), Muricy (1999), Seligmann-Silva, (1999), o fizeram descobrir a originalidade dessa nova visão, ainda melhor compreendida com a leitura das Obras Escolhidas I, II $(1987,1994)$ e, especialmente, III (1989), de Benjamin, que lhe permitiu descortinar outro cenário da história urbana europeia, onde as paisagens observadas se projetavam em diferentes espaços, nas ruas e ruelas, configuradas não apenas numa classificação geográfica, mas visualizadas nas representações sociais projetadas no real e no imaginário, componentes do enredo do cotidiano urbano, como nova via de compreensão do processo histórico.

Ao chegarmos à Praça do Ferreira, na sua definição "antigo coração da cidade, hoje estampa da marginalidade social contraditória" (Nome completo do depoente, data), ele nos fez compreender uma afirmação comumente mal compreendida e interpretada, a de classificar o cearense um povo sem memória, sempre em busca de novas paisagens. Toda cidade, por mais antiga que seja, dificilmente consegue preservar todo o seu patrimônio, uma vez que a abertura de novos espaços e o traçado de outras configuraçôes são impulsionados pelo caráter demolidor de se considerar algo como arcaico.

É como se o presente, passageiro e fortuito, estivesse liberto do passado, mais maldito do que bendito, ante a ânsia do enlevo de um futuro redentor. Segundo sua visão sempre aberta, em busca de novas revelaçôes, Fortaleza se projeta como uma adolescente, ainda imatura, se confrontada com outros grandes centros urbanos, como o Recife ou Salvador. Assim, o ímpeto demolidor da moderniza- 
ção, decantada e mal definida, que a cada dia consegue avançar, com a abertura de novas vias e outros espaços, esbarra numa fragilizada resistência dos que tentam preservar o patrimônio público e privado, mas que dificilmente se faz ouvir ou respeitar pelas autoridades constituídas e pelos modernizadores demolidores, donos do capital, sempre em busca de maiores lucros, deixando em segundo plano os valores culturais e o próprio senso humanitário.

Mas se formos confrontar o acervo patrimonial da capital cearense com o de outras grandes cidades regionais, Fortaleza pouco apresenta da arte e arquitetura barroca, por exemplo, uma vez que a maioria das principais edificaçóes públicas, incluindo a própria catedral, é bem mais atual, ou seja, elas foram construídas no final do século XIX, salvo raras exceçóes, como a pequena Igreja do Rosário, que serviu de matriz das cerimônias religiosas, enquanto a antiga catedral estava sendo reconstruída, ou a Igreja do Patrocínio, localizada na Praça José de Alencar, a segunda maior após a do Ferreira, que durante muitos anos serviu de terminal à maioria dos ônibus que se deslocavam aos principais bairros da cidade.

$\mathrm{E}$ até os anos sessenta, do século passado, na verve popular, havia três sinfonias inacabadas na capital cearense: o Cine Sáo Luiz, a Catedral, que apesar de um modelo medieval nada tinha de arcaico em seu entrono, e o Porto, cuja construção se arrastou ao longo dos anos, em virtude não apenas dos limitados recursos financeiros disponíveis, mas devida a pouca profundidade do mar e o constante deslocamento de areia, impulsionado pela ventilação contínua e em virtude da pouca ocupação humana nas suas imediaçóes.

A inauguração do São Luiz, no modelo arquitetônico do principal cinema recifense, também de propriedade do cearense Severiano Ribeiro, constituía um sonho dos habitantes da cidade, que se sentiam inferiorizados ante o perfil mais moderno e atraente do Recife e que costumavam definir alguma edificação pública ou privada da capital, com maior significância, como "a maior do norte e nordeste do país".

A antiga Catedral fora demolida por ser considerada mal estruturada e de modelo pouco original, devido à carência de recursos financeiros, mas as obras de reconstruçáo se arrastaram por décadas e somente nos anos setenta do século passado ela foi inaugurada.

As edificações urbanas do centro da cidade de valor simbólico e prático são poucas, além do antigo Palácio do Governo, o prédio da Assembleia Legislativa do Estado, o Palácio do Bispo, hoje sede da Prefeitura Municipal, o Quartel da 10a Região Militar - no espaço onde foi instalada a antiga Fortaleza de Nossa Senhora da Assunçáo, no mesmo local onde os holandeses instalaram o seu forte defensivo, uma vez que é o único local com elevação natural no centro da cidade - o antigo Presídio, hoje centro de vendas artesanais, o mais figurativo prédio urbano e o Teatro José de Alencar, só concluído na primeira década do século vinte. O ferro, 
material básico empregado na maior parte do prédio do teatro, foi importado da Escócia e permanece como um demonstrativo da viabilidade de modernização dos prédios públicos, que serviriam de cartão postal da cidade. Outro prédio, que não foi tombado como Patrimônio Público, é o do antigo Seminário da Prainha, instalado ali em 1864, após a criação da Diocese de Fortaleza, mas remodelado com material mais contemporâneo, como as chamadas "pastilhas de parede".

Segundo as lembranças de Francisco, até o final dos anos setenta, tudo convergia para a Praça do Ferreira e, na linguagem comum, "ir à Praça", significava deslocar-se até o centro da cidade. Além do Cine São Luiz, localizado no principal edifício, no seu entorno situavam-se as melhores lojas da cidade, como a Flama, denominada símbolo de distinção nas propagandas de rádio e nos principais jornais, as Lojas Brasileiras, mais conhecida como Lobrás, que se destacava das demais por possuir a valorizada "escada rolante", as Casas Pernambucanas, a Casa Parente, com sua variedade de produtos, incluindo roupas femininas e outros adereços que vinham de São Paulo, a Rouvani, a melhor em roupas masculina. Havia também a famosa Casa Bicho, de propriedade de um comerciante de origem libanesa, com variedade e qualidade de chapéus caros e procurados pelos alta sociedade local e a Loja de Variedades, completando a lista das mais procuradas. Náo se deve esquecer outras de menor porte que por estarem situadas no centro, eram tidas como de qualidade: as Lojas Exquisita e a Exquisitinha, do mesmo grupo comercial, eram as mais procuradas pelos mais bem aquinhoados, que faziam questão de comprar os últimos lançamentos.

Além do São Luiz, outros cinemas também ali se localizam, como o Cine Diogo, o segundo na escala de classificação, o Jangada, mais procurado pelos inveterados amantes de filmes pornográficos, o Samburá, de melhor porte, todos eles localizados nas ruas centrais, não muito distantes um do outro, com exceção do Cine Art, situado um pouco mais distante do centro, na verdade, menos de cinco quadras da Praça do Ferreira, na Praça Castro Carreira, onde se situava a antiga Estação Central, depois Estação Professor João Filipe, onde partiam e chegavam os trens vindos das regióes norte e sul do estado, respectivamente das cidades de Sobral e do Crato.

Os dois principais pontos de taxi, na época mais conhecidos como "pontos de carros de praça”, também compunham a paisagem do principal lugar de convergência da cidade, além da principal padaria, a Lisbonense, de uma tradicional família portuguesa, sem esquecer as duas principais farmácias, a Pasteur, a mais antiga, e a Oswaldo Cruz, onde alguns medicamentos preparados eram vendidos sem a necessidade de receitas médicas.

Havia também outros pequenos espaços comerciais, como a lanchonete do Mundico que servia o famoso refresco Pega-Pinto, onde se encontrava uma variedade dos chamados refrescos, feito de ervas naturais. A Leão do Sul atraía os 
transeuntes, que matavam a cede com o gostoso caldo de cana, servido com gelo, por isso mais valorizado, embora o atrativo maior estivesse nos pastéis, de queijo ou de carne, cujo "cheiro contagiante", definia aquele espaço social. Os chamados Cafés atraíam os fumantes, pois no balcão, onde eram servidas pequenas xícaras, havia o conhecido "acendedor de cigarros", um pequeno depósito mantido a querosene, em cuja extremidade se destacava uma chama acesa em uma corda.

Um detalhe sempre lembrado nas referências à Fortaleza do pós-guerra. resultava "da malandragem astuciosa da moçada", assim configurada: os jovens, após a saída ou mesmo antes de ingressarem no Cine São Luiz ficavam bem na esquina das ruas Major Facundo com a Guilherme Rocha, mais conhecida na época como Rua do Ouvidor, interditada ao tráfego de carros para facilitar a comunicação com a outra principal praça da cidade, a José de Alencar, na linguagem popular, Zé de Alencar. As moças que por ali passavam tinham todo o cuidado de segurar nas bordas das suas saias, pois o forte vento sempre se lhes apresentava como um desafio considerado ameaçador de "levantar as saias das meninas, nem que fosse de raspão, de forma relâmpago, deixando aquela brecha visual”. E os assobios constantes irritavam ainda mais as moças de "boa família”, só as "avoadas" gostavam dessa ocorrência banal, ao mais das vezes considerada mal vista.

Ao indicar os pontos-chave do centro da cidade, reveladores dos múltiplos sentidos nela projetados, fica explícito na arguta análise do velho professor que não é só através da razão que se pode compreender e indagar acerca dos intrincados enigmas, que se entrecruzam em qualquer história de uma cidade, mas o panorama é bem mais abrangente, onde o real e o imaginário se associam, sem o objetivo de um confronto competitivo, na busca de uma verdade autêntica, afinal o conceito de parresia, moldada por Foucault nos parece mais aproximativo, na expressão de um sentido espontâneo, uma vez que “...consiste em dizer a verdade, sem dissimulação nem reserva nem cláusula de estilo nem ornamento teórico que possa cifrá-la ou mascará-la” (Foucault, 2011). Nessa perspectiva, está a Fortaleza sem memória, como ressalta nosso entrevistado:

Ela ainda é jovem e imatura, se comparada a outras capitais de tradiçóes coloniais. No sentido patrimonial, seu arcabouço histórico a projeta como se fosse ainda adolescente, insegura ante um público descrente, revelador de uma contraditória causalidade explicativa, que atinge e macula a memória, que lhe é atribuída, mas ela possui a sua razão de ser. (Francisco José de Castro Oliveira, 2018).

Ele insiste em afirmar, nas suas recordaçóes, o valor intrínseco da temporalidade vivida, ao reconhecer que o tempo presente jamais se revela entrecortado, com a tradicional separação entre o ontem, o hoje e o amanhã, pois a configuração 
atual da cidade náo foi fruto de um acaso, mas moldada nos contrastes revelados entre o almejado e o realizado, o sonhado e o obtido nos rastros das experiências vivenciadas, com todas as mazelas e incongruências. E a Fortaleza hoje configurada como o terceiro polo de atração turista do país ainda se revela mutilada por suas contradiçóes sociais, expressas na concentração de renda de uma tradicional elite, sempre a reboque do poder público que a protege e defende contra possíveis rupturas da sua configuração política e social.

A sua narrativa é pontuada mais indagaçóes do que de respostas ante uma tradição bairrista, tão comum em nossas reminiscências: por que o impulso modernizador de diferentes espaços, focos de atração turística, se revela mais impetuoso do que a realidade visualizada pelo olho clínico de um historiador consciente das contradiçóes sociais, cada vez maiores, tentando negar os discursos proferidos em prol da projeção de uma cidade modelo, no rol turístico da globalização?

Nas suas ruas mais preservadas, com os sinais de trânsito em cores vivas e uma iluminação condizente com o modelo almejado, também se visualizam os indicadores de outras realidades, expressos nos chamados "flanelinhas", que insistem em limpar os para-brisas dos carros parados momentaneamente ante os semáforos - pois talvez não só "dos trocados" recebidos eles conseguem sobreviver, sendo comum o envolvimento de grande parte deles com o comércio de drogas, pela falta de outra perspectiva de vida, cada dia mais sofrida do que vivida.

$\mathrm{Na}$ opinião do nosso narrador, bem próximo ao edifício onde reside, num dos bairros mais valorizados, há um amontoado de casebres ocupados por moradores que procuraram sobreviver com o contínuo subemprego, sempre presente em diferentes espaços da cidade. Não se pode separar uma possível área nobre da cidade de outra bem inversa, sem a mínima estrutura sanitária e com precárias condiçóes de sobrevivência. Desde o desabrochar da capital, em torno da cada área nobre sempre foi fixado o outro lado da moeda. Assim, cada espaço ampliado sempre se projeta cercado de moradores que não podem usufruir do tal bem-estar social, tão decantado nos discursos e projetos oficiais; a configuração do traçado urbano vai se configurando como uma divisória de canteiros sociais, cercados de uma vegetação desfigurada e temida.

Mais uma vez o nosso memorialista recorre ao teor das revelaçóes temporais, que bem expressam a urdidura das relaçóes sociais, sempre entrelaçadas, jamais dissociadas, estampando o pano de fundo das múltiplas paisagens, expressivas do emaranhado de açóes e reaçóes, que se projetam no deslocamento dos múltiplos cenários, observados no olhar do espectador, projetor de enredos, individuais e sociais, estampados no cotidiano urbano, seja o revelador de espaços mais cobiçados ou dos recônditos insignificantes, da periferia urbana, mas a temporalidade não se fragmenta, seguindo o enlace contínuo entre o que foi, continua sendo, fragmentado pelo peso do vazio da vida globalizada, onde o amanhá parece 
além de incerto, indesejável.

Ele nos lembra de uma notícia, publicada em um jornal local, expressiva das contradiçóes do cotidiano urbano, levando a estabelecer uma comparação entre a Fortaleza do pós-guerra com a dos dias atuais. Ele tinha apenas quatorze anos e o ar provinciano ainda pairava nas representaçóes de cenas cotidianas observadas. Na época, eram poucas as ruas asfaltadas na cidade e a maioria delas, sobretudo as que se distanciavam do centro, tinham como cobertura um calçamento tosco de pedras fragmentadas, que se soltavam facilmente, tornando mais vagaroso e incômodo o percurso dos ônibus, sempre num balanço contínuo, onde poucos carros particulares circulavam. O humorista Renato Aragão contava, em uma de suas piadas, que conhecia um indivíduo tão preguiçoso que antes de tomar um remédio com a recomendação em destaque na bula de "agite bem antes de usar", preferia colocar o vidro do medicamento no bolso, apanhar um ônibus, percorrer alguns quarteirôes e logo o problema estava resolvido sem exigir qualquer esforço muscular.

E hoje a propaganda contínua da Prefeitura Municipal destaca, dentre outras inovaçóes levadas adiante, o projeto Bicicletar, como incentivo a novas modalidades de mobilidade urbana, mas no mesmo jornal onde a notícia alvissareira foi estampada, outra mensagem é projetada com a seguinte cobrança: "Cadê a manutenção do Bicicletar, Prefeito?”. A coincidência é irônica e reveladora das contínuas contradiçóes entre os objetivos sociais propostos pelas autoridades constituídas e os resultados sociais obtidos. Apesar do apoio de um patrocinador, a busca de uma cidade menos poluída e com alternativas compensadoras ao transporte público esbarra num problema corriqueiro, a precária manutenção dos serviços e muitas das chamadas "estaçôes" enfrentam problemas de internet que dificultam a liberação das bicicletas, muitas delas avariadas, com pneus danificados ou com as chamadas selas quebradas. Há um serviço de atendimento às reclamaçóes, da empresa Serttel, ainda precária, com a burocracia pesando mais forte do que a devida atenção aos prejudicados e até algumas das decantadas "ciclofaixas" se apresentam bem deterioradas. E se um tipo de serviço prestado com o devido apoio de patrocinadores, beneficiados com a propaganda estampada nas bicicletas, não satisfaz às exigências cotidianas, imaginem aqueles serviços básicos, como saneamento e assistência sanitária, serviços ainda restritos a determinadas áreas consideradas "mais nobres da cidade".

$\mathrm{Na}$ opiniáo do entrevistado, se formos considerar o alcance social das medidas inovadoras postas em prática em diferentes espaços da cidade, logo se percebe uma assistência voltada ao atendimento das necessidades pessoais, como a prática de exercício físico, falando mais alto do que os objetivos sociais, quando os efeitos benéficos do passeio de bicicleta deveriam estar voltados ao atendimento de uma prioridade social, como o deslocamento de moradores de bairros perifé- 
ricos, dificilmente atendido pela inovação urbana, aos pontos centrais da cidade ou a seus locais de trabalho. Na sua visão, a paisagem mais valorizada, no palco urbano, se projeta como essencialmente egocêntrica, presa ao espelho narcisista, tão em voga na defesa do individualismo da atualidade, melhor definida em "A Era do Vazio", "O império do efêmero" e "A Felicidade Paradoxal" (Lipovetsky, 2005, 2009, 2014).

Nos dias atuais, mais procurados e valorizados do que os antigos pontos de encontro do centro da cidade, entre as Praças do Ferreira e a José de Alencar e nas ruas que as aproximam, os Shopping Centers constituem novos espaços mais condizentes com a busca de segurança e conforto do que aquele ambiente inseguro, castigado pela ação dos fortes raios solares, pelos assaltos constantes noticiados nos programas policiais das rádios e dos canais de televisão, registrados em diferentes pontos de circulaçáo de pessoas. Essas, em sua maioria de origem menos favorecida, como se constata nas roupas, em sua maioria, surradas e com adereços populares, embora a classe média se faça representar pela maioria da mão de obra empregada no comércio. As maiores e representativas lojas, que se situavam nos pontos-chave do centro da cidade, foram transferidas para os shoppings, embora algumas ainda sirvam de atraçáo a uma clientela permanente, como as Lojas Americanas ou a tradicional Casa Pio, mas são uma minoria e, segundo o olho atento do nosso narrador, essas mesmas lojas, que também foram instaladas nos shoppin$g s$, apresentam uma diferença, uma vez que os preços ali cobrados estão voltados à cobertura dos gastos de manutençáo cobrados na alta cotação desses novos centros comerciais. As agências dos principais bancos públicos, como a do Banco do Brasil e da Caixa Econômica, ou de particulares, como a do Bradesco e do Itaú, ainda permanecem nas ruas do centro, embora a maioria dos bairros também possuam agências, associadas ao comércio lá instalado.

Além dos principais pontos de venda, nos shoppings, os restaurantes e as lanchonetes, hoje mais conhecidas com novas denominaçôes em inglês, expressivas dos pratos ofertados, pouco a pouco foram sendo mais procurados, levando os seus proprietários a adotarem estratégias para atrair mais clientes. Mais do que uma simples oferta variada de pratos mais atrativos, a decoraçáo interna dos mesmos é considerada "uma tática para tirar esse estigma do shopping como local prioritário de vendas variadas”.

Muitas pessoas vão até lá apenas efetuar compras com maior segurança e conforto, mas ao se depararem com um local mais atrativo para refeiçóes, se deixam levar não apenas pela propaganda, mas segundo um expert desse comércio, "o triunfo sobre o público toma corpo na estratégia de ressignificar o espaço ocupado", como uma tentativa de atrair turistas e conterrâneos. Para tanto, alguns restaurantes mantém parcerias com os hotéis mais procurados. Mesmo assim, uma particularidade chama a atenção dos visitantes: a maioria dos que trabalham em 
lojas do shopping preferem frequentar restaurantes com cardápio mais barato, localizados fora desse espaço privilegiado. Por sinal, tudo é mais caro nesse novo ambiente de lazer e de compras de produtos mais valorizados. Em alguns, passou a ser permitida a entrada de clientes com seus pets, em geral de raça bem avaliada no mercado canino, como uma comodidade e atração para quem por ali se desloca. Na opiniâo do nosso depoente, a supervalorização dos animais de criação, bem explorada pelos seus revendedores e proprietários das mais variadas clínicas especializadas, pode ser explicada no valor da companhia dos pequenos companheiros do cotidiano, em especial para pessoas de mais idade, "após os quarenta", que vivem sozinhas, cercadas de isolamentos mais sociais do que espaciais. E ele, que tem sob seus cuidados um cachorrinho e um gato de raça, lamenta a inexistência de medicamentos genéricos destinados aos animais, assim, muitos dos que ele costuma comprar lhe custam um preço mais elevado do que a medicação para si próprio. É o resultado da sociedade hiperativa e superconsumista, onde tudo se projeta como mercadoria a ser explorada ao máximo.

Ainda no centro da cidade, diversas edificaçóes de pequeno e médio porte foram demolidas e os seus espaços transformados em estacionamentos de carros. Essa, uma fonte de renda bem valorizada numa cidade onde o desejo de possuir um carro, opção mais rápida e segura de transporte, sem esquecer o significado simbólico da posse de um carro como confirmação de uma situação financeira melhor estabelecida. Muito se fala das vantagens e da segurança de se locomover de bicicleta pelo centro da cidade, mas para o observador atento aos contrastes do cotidiano urbano, quais seriam essas, numa temperatura diária de mais de $30^{\circ}$, no "vai e vem" de transeuntes suspeitos, em sua maioria, pois podem ser assaltantes ou um daqueles jovens antes denominados "trombadinhas", porque em geral empurravam os transeuntes, sobretudo pessoas de idade ou mulheres, mais fáceis de serem dominados.

A ideia de uma cidade limpa em duas faces, ou seja, com ruas sem acúmulo de lixo e isenta de possíveis "larápios" não é tão atual, vem desde o século passado, quando um Coronel, que "colocara ordem na casa", implementando um rigoroso policiamento e emprego dos presos na limpeza das ruas centrais da cidade. Como reconhecimento pelo seu trabalho em prol da segurança pública, ele foi eleito prefeito da capital e, diariamente, mandava que fosse cumprida "a limpeza do perfil da cidade", com o afastamento dos mendigos do centro que costumavam ali permanecer diariamente "em busca da caridade pública" (Francisco José de Castro Oliveira, 2018).

Se nos dias atuais os shoppings se projetam como uma das provas identitárias de cidades de médio ou grande porte, como Sobral, Juazeiro do Norte ou mesmo de município componentes da Grande Fortaleza, como Maracanaú ou Euzébio, com poucas horas de viagem se pode visualizar outras paisagens bem mais 
pesadas do que a tradicional identificação de um solo árido ou de uma vegetação rasteira e temporária. Refiro-me à centralização da riqueza do estado do Ceará, predominante na referida região metropolitana, cuja concentração econômica a beneficia de forma excessiva, deixando a reboque a quase totalidade dos municípios do estado. Na visão do arquiteto Airton Montenegro, "o resultado disso é um Estado com cidades bastante frágeis, cuja base econômica é muito insuficiente mesmo com a população pequena que elas têm" (Damasceno, 2019a).

A preocupação do governo estadual, que se defronta com o baixo índice de $2 \%$ de participação na economia nacional, motivou a elaboração de planos em busca de possível diminuiçáo do contínuo deslocamento de grande parte da população interiorana em busca de melhores condições de vida na capital. Resta aguardar se os possíveis planos de uma melhor distribuição de renda na rede urbana local tornar-se-âo viáveis sem o decisivo de apoio do governo central, o que parece improvável, com o federalismo cada vez mais crítico de um presidente inconstante, cujos contínuos pronunciamentos políticos só contribuem para tumultuar o panorama político e atrapalham a estabilidade econômica almejada, assim, o Nordeste todo passou a ser denominado por ele com o termo pejorativo de "Paraíba". A arguta análise do Professor Diatahy Bezerra de Menezes, da Universidade Federal do Ceará (UFC), bem define o panorama atual: "qualquer porcaria que se produza no eixo Rio-São Paulo é nacional. Quando é aqui, é provinciano, é regional e local. É nesse sentido, que eu digo que a gente mora na fronteira da Tchecoslováquia, que nem existe mais" (Leal, 2019).

As desigualdades sociais falam mais alto do que a propaganda multicolorida, cada vez mais propagada nos mais variados canais de comunicação em prol da indicação e do reconhecimento de uma cidade atraente, convidativa aos turistas, beneficiada com o clima agradável e a intensa luminosidade solar - poucos são os meses chuvosos. O perfil do cearense projetado nas propagandas sempre o configuram com um indivíduo cordial e sorridente, contrariando a tristeza estampada nos grandes centros urbanos do país, onde a insegurança e o peso dos problemas sociais tornam insignificantes os espaços multifacetados: é como se a nódoa dos problemas embaçasse as paisagens urbanas projetadas na tela do cotidiano.

No pós-guerra, a modernização da cidade aparecia mais nos discursos políticos proferidos, em especial nos períodos eleitorais, pelos candidatos ansiosos por um apoio popular. Dentre as promessas redentoras se destacava a proposta de afastar do centro da cidade, em especial, das duas principais praças, os mendigos, encaminhando-os para abrigos; no caso dos mais jovens, se possível, enviá-los de volta ao interior do estado, de onde tinham fugido. Como estampa da realidade social conflitante, além da ação incômoda dos mendigos, o comércio ambulante sempre foi combatido, mas segundo o nosso depoente, também aproveitado, explorado pelos médios e pequenos comerciantes, que se utilizavam desses ven- 
dedores ambulantes para facilitar a venda dos produtos de seus estabelecimentos comerciais.

O percurso, que interligava as duas principais praças da capital, cada dia mais passou a ser explorado por esses vendedores ambulantes, que aproveitavam a oportunidade de mais espaço para oferta "das suas bugigangas e de aprestamento dos mais variados produtos, de pentes e espelhos aos quadros e enfeites domésticos ou mesmo peças de vestuário, fruto do trabalho artesanal que sempre marcou o comércio local.

A paisagem de maior projeção de Fortaleza, que se pretende pós-moderna, se apresenta como testemunho da continuidade dos velhos problemas cotidianos que se sucedem numa cadeia sólida, representativa da permanência dos dilemas sociais não superados. Num país com mais de 13 milhóes de desempregados, novas ofertas de subemprego se ampliam, como a opçâo de recorrer ao Uber como uma compensação ante a pouca oferta de emprego estável,

... são 5,5 milhôes de profissionais cadastrados em plataformas de mobilidade e entrega de produtos, como Uber, 99, Cabify e iFood, de acordo como Instituto Locomotiva. Os dados levam em conta os profissionais autônomos e os que têm emprego fixo, mas usam a ferramenta para complementar a renda. (Damasceno, 2019b).

Trata-se de uma autonomia desdenhosa, que não garante estabilidade profissional à maioria dos seus agentes que não veem outra saída de subsistência ou aos que possuem um emprego que não lhes garante o sustento almejado.

Indago ao entrevistado, como ele visualiza o papel do historiador nos dias atuais, como ele se sente ante as mudanças contínuas registradas com um impacto demolidor, impulsionadas pela globalização, em diferentes pontos do mundo, o que não mais permite sobrevivência àquela velha tradição que dividia o mundo de acordo com a taxativa dualidade que separava o bom do mau, o avançado do retrógrado, o civilizado do apátrida e sua resposta é taxativa: "a barbárie parece ter voltado a figurar em diferentes espaços culturais, como uma onda demolidora do sonhado processo civilizatório, onde a possante locomotiva do Ocidente fulgurava como condutora da contínua trilha a ser percorrida em busca da sonhada igualdade, cultuada bem antes do racionalismo francês, antes mesmo do desabrochar da cultura greco-romana". (Nome completo do depoente, data).

$\mathrm{Na}$ sua visão, vivemos em mundo em decomposição, projetada inclusive em cada cena do cotidiano urbano, que aproxima o distante do próximo, mas propicia, a cada passo, o isolacionismo do indivíduo, preso aos grilhóes de uma ultramodernidade, onde a tonalidade fugidia de um bem-estar almejado esbarra no desmoronamento dos valores éticos, antes consagrados pela tradição, defensora 
de uma hegemonia do Ocidente.

E a solidão e o vazio existencial não têm fronteiras, cada vez mais presentes nos mais diferentes espaços, propiciando um redimensionamento dos princípios norteadores da ação social, quando o niilismo retorna às reflexóes acadêmicas como o mais adequado paradigma para definir a incongruência das propostas norteadoras de uma possível saída ante a catástrofe temida, que não mais se apresenta como uma etapa a ser vencida. Não é à toa que as teorias explicativas da razão do náo-ser, que pareciam inviáveis, conceituadas como desvios da racionalidade, voltam ao cerne das discussôes no meio acadêmico e que o "Anticristo" e "Além do Bem e do Mal" de Nietzsche são rediscutidos, embora nem todas as análises apresentadas constituam reafirmação do vazio ético, tão condenado pelos seguidores do racionalismo, quando um novo edifício conceitual redimensiona os princípios conceituais do ser e do agir, sem o pesadelo de um caos (Mosé, 2018).

Quando lhe indaguei como ele podia associar esse "caos civilizatório" com a realidade cotidiana de uma cidade como Fortaleza, sua reposta foi taxativa:

O processo histórico não pode ser fracionado, como se as manifestações enigmáticas da vida urbana se restringissem a um espaço limitado por indicaçôes de rígidas fronteiras. $\mathrm{O}$ espaço geográfico se envolve com o espaço cultural, que não pode ser compreendido sem a análise das contradiçóes sociais, sempre presentes, na pluralidade espacial que compóe o quadro urbano, só compreendido quando analisado numa visão transdisciplinar e não apenas em um limitado campo do conhecimento. $\mathrm{O}$ que é histórico náo deixa de ser social, econômico, político, cultural ou mesmo filosófico, afinal o pensamento humano constitui a busca de uma luminosidade reflexiva, racional, mas sem se dissociar do sentimental e do imaginário. Cada espaço urbano ocupado, observado, reconhecido ou não reconhecido, não importa a temporalidade evocada, constitui um quadro refletor de uma maneira de ser e pensar, bem mais abrangente e representativa, com os valores morais e culturais presentes em cada lar, em cada bairro, nos espaços públicos e privados que se entrecruzam. (Francisco José de Castro Oliveira, 2018).

Ainda, segundo ele:

As cidades se nos apresentam como livros abertos, com capítulos diversos e múltiplos cenários, sempre à espera de reflexóes que lhes possam dar um sentido de ser. Não desejo fazer ressurgir a mensagem redentora que me alimentava quando ingressei na universidade como aluno do curso de História, no aguardo de uma possível ação redentora que se tornaria rea- 
lidade com o surgimento de uma revolução comunista, mas apenas deixar bem claro que o valor da análise histórica é nos fazer compreender as contradições dos embates constantes de diferentes representaçóes, reconfiguradas após uma devida reflexão histórica que nos permite compreender o que parecia incompreensível. (Francisco José de Castro Oliveira, 2018).

Antes, até os anos sessenta do século passado, as cidades eram consideradas núcleos vitais da cultura, mas visualizadas de forma isolada, pois os rastros do nacionalismo e do regionalismo, consagrados como indispensáveis ao entendimento de qualquer enredo histórico, ainda deixavam marcas profundas nos estudos apresentados. Embora o embate entre dominantes e dominados na projeção do processo civilizatório, quando a discussão sobre a configuração das cidades de regióes subdesenvolvidas suscitava diferentes análises, procurasse defender os espaços urbanos num sentido nacionalista, na tradição cultural de Fortaleza, ainda imperava "o domínio de um chamado bairrismo provinciano". Esse, frente a qualquer melhoria registrada, levava a uma definição bem peculiar do tradicionalismo regional, ao afirmar que tudo de representativo observado o cenário urbano local, era "o melhor ou a melhor [instituição ou edificação] do Norte e Nordeste" (Francisco José de Castro Oliveira, 2018).

Nos dias atuais, os valores e as visóes foram alterados, quebrando as fronteiras que antes se antepunham entre os diferentes polos urbanos. Os usos e costumes não mais representam apenas os valores e ou tradiçóes locais, mas se revelam mesclados com o peso da globalização. A tradicional maneira de ser, de vestir e agir perdeu o peso nas tradiçốes locais, trituradas pelo peso dos valores internacionais tâo bem expressos em denominaçóes e expressóes da língua do capital globalizado, o inglês. Mas o perfil urbano da capital cearense, para nosso entrevistado, sempre se configura no seu verso e reverso, quando o luxo e o consumo globalizado náo se dissociam da miséria e da fome presentes em diversos espaços, que se envolvem em torno das ilhas do bem-estar sonhado pelos agentes da

desterritorialização, ou seja, espaços sem fronteiras definidas. São partes constitutivas de uma cidade desumanizada, envolta no manto da globalização, onde as contradiçóes cotidianas se decompóem ante a crueza da individualização cada vez mais acentuada dos cidadãos. E a imagem que se projeta ante o olhar atento de cada observador não é unitária, duas paisagens se delineiam, a paisagem natural e aquela cujo teor depende do olhar que a contempla, dependendo do seu estado de espírito, a paz ou a guerra interior se revelam de acordo com a visão do observador de paisagens redimensionadas, de acordo como ímpeto da subjetividade. (Francisco José de Castro Oliveira, 2018). 
As projeçóes reveladas ante o olhar indagativo do entrevistado nos remetem a duas Fortalezas: a fortalecida pelo engodo da globalização e da espetacularização projetada nas revelaçóes midiáticas e a desfortalecida, estampada na ação dos chamados "flanelinhas" em busca de um sustento ou na do subemprego cada vez mais presente no levantamento dos dados estatísticos, a cargo de entidades governamentais.

A manchete de um jornal local comemora a $28^{\circ}$ edição do chamado Fortal, que provocou um trânsito intenso em um das principais avenidas do bairro Aldeota, a Santos Dumont, com a participação não apenas de jovens da cidade, mas de turistas atraídos pela propaganda dos "dias de turismo/ lazer", que proporcionam uma série de atividades complementares envolvendo o comércio e outros serviços complementares, abrindo vaga de empregos temporários aos desocupados, embora a renda real seja canalizada para as companhias organizadoras do tradicional evento. No evento estavam previstos os blocos comandados por Ivete Sangalo e Wesley Safadão.

Para o nosso narrador, o pano de fundo da mercantilização do lazer também se projeta nas comemoraçóes religiosas. Antes, as cerimônias mais significativas, realizadas nas Igrejas, eram marcadas pelo recolhimento e concentração dos fiéis que até ali se deslocavam. O único espetáculo público, nas comemoraçóes religiosas eram as procissóes, embaladas por cânticos tradicionais em homenagem ao(s) padroeiro(s), quando o recolhimento e a concentração de cada fiel revelavam o sentido das manifestaçóes religiosas. Para ele:

Nos dias atuais, o que interessa é o show a ser apresentado os gritos coletivos, expressivos do sentido de uma religiosidade dominada pela força da mídia, quando o sentido de uma cerimônia religiosa é travestida de espetáculo a ser exibido e, em geral, os cantores mais aplaudidos são aqueles sacerdotes ou mesmo religiosas que se apresentam como cantores de programa de TV, trajando uma roupa enfeitada, de acordo com a conveniência do momento, todos rebolando em nome da fé capaz de mover montanhas, mas que, ao sair dali, voltam aos seus individualismos, incapazes de se voltarem aos contrastes sociais que os cercam. A Igreja dos Pobres, fruto do Concílio Vaticano II e da teologia da Libertação, foi encoberta com uma fantasia mais contagiante, expressiva de se encarar o momento de oração como uma atividade de lazer. (Francisco José de Castro Oliveira, 2018).

Se fôssemos percorrer outros espaços da cidade, outras paisagens e outros atores ocupariam o palco do cotidiano; numa cidade de entraves e contrastes, 
onde a dialética dos espaços e a das configuraçóes representadas se mesclam com as contradiçôes sociais estampadas nas açôes associativas e dissociativas, reconfiguradas nos discursos proferidos pelas autoridades constituídas, onde o real e o imaginário se mesclam a cada instante, apresentados através de um imagem incompleta da realidade social, que tem duas fazes antagônicas e contraditórias.

A complexidade social exposta no cotidiano nos faz refletir a respeito do alcance analítico revelado pelo múltiplo enredo da História Urbana, onde as diversas manifestaçóes componentes do pensar e do agir humano se projetam na diversidade de fontes, que nos revela o alcance da interdisciplinaridade, sempre implícita nos enredos configurados que se apresentam como uma representatividade da chamada rede urbana, afinal a realidade social náo representa a essência da historicidade, porque pouco ela nos revela se isenta do enlace com o imaginário.

\section{Considerações conclusivas}

A cidade, sempre associada a espaço e tempo, não pode ser compreendida se visualizada num rigoroso corte cronológico, estratégia que infelizmente ainda hoje se faz presente em muitas produçóes acadêmicas, como se a continuidade história não existisse. Conforme nos deixou claro Bernard Lepetit (2001), a recomposição do passado é constituída com configuraçóes do presente, que deixam explicitas as proposiçôes a serem analisadas. São as indagaçóes do presente que nos fazem voltar ao enredo anterior ao momento atual, a fim de melhor entender as formas de experiências múltiplas, quando as práticas sociais nos ajudam a compor o complexo quadro de uma temporalidade plural.

O perfil hoje projetado de uma cidade como Fortaleza, tem seus pontos específicos consolidados, identificadores de suas peculiaridades, mas eles perdem o seu significado representativo se não os associamos à complexa rede urbana na qual está inserida. As cidades são como as pessoas, com traços comuns dos diversos agentes e enredos que as envolvem, mas a especificidade do perfil de cada uma delas não a distância do elo comum das configuraçôes urbanas.

As reminiscências de um professor dedicado à História Urbana, sem menosprezar a variedade de fontes disponíveis, se apresentam como uma possibilidade peculiar e significativa de melhor compreender o enigma urbano. A subjetividade pesa forte, mas não se revela isenta de um enredo histórico projetado ao longo do período rememorado, onde a memória individual não se dissocia de uma memória social, afinal nenhum enredo histórico tem alguma validade se limitado à projeção de experiências individuais.

Nessa modalidade de rememoração acerca de um roteiro histórico, apesar 
da narrativa se concentrar em um testemunho individual, o conteúdo das experiências vividas não é egocêntrico, porque a sua razão de ser só se revela representativa se envolvida num cenário social mais amplo, onde os conflitos e a troca de experiências permite ao leitor ir além de um simples relato sequencial. A visão analítica de um depoente nos permite rever ideias pré-concebidas que nos foram transmitidas pela visão tradicional, que consciente ou inconscientemente busca uma homogeneização do complexo enredo de uma rede urbana, projetada além do regional, mas conservadora de resquícios do passado no presente, nem sempre condizente com as expectativas alimentadas.

Reconstruir um passado que não pode ser apagado, não garante ao leitor uma revelação promissora de um amanhã idealizado, racionalizado, de acordo com modelos explicativos presos a enunciados dogmatizados, mas a sua narrativa permite ao leitor levantar novas questóes ante os dilemas do peso da metropolização de grande número das capitais dos estados brasileiros, como Fortaleza. De acanhada cidade "cercada de problemas por todos os lados, no pós-guerra", como nos lembra nosso entrevistado, hoje se orgulha da modernidade nela projetada com as imposiçôes da globalização, mas sem conseguiu se livrar dos entraves sociais que a deformam, desfazendo o modelo idealizado de progresso, sempre enunciado, mas não realizado num sentido social mais equitativo. São os desafios da urbanização à espera de medidas concretas que possam atender os anseios populares, onde o privado não continue dominando o público.

$\mathrm{O}$ testemunho do nosso entrevistado não nos traz uma resposta concreta ante os dilemas do mundo atual, na Fortaleza de hoje, mas suscita novas indagaçóes, questionadoras e desafiantes, que nos incentiva, afinal a razão de ser da História é levantar questôes e não impor conclusóes herméticas, dogmatizadas.

\section{Referências}

ABREU, João Capistrano de. Capitulos de História Colonial: 1500 - 1800. Rio de Janeiro: Civilização Brasileira; Brasília: INL, 1976.

BENJAMIN, Walter. Documentos de cultura, documentos de barbárie: escritos escolhidos. São Paulo: Cultrix; Edusp, 1986.

- Obras Escolhidas I: Magia e técnica, arte e política. $7^{\text {a }}$ ed. São Paulo: Brasiliense, 1994. 
. Obras escolhidas III: Charles Baudelaire, um lírico no auge do capitalismo. São Paulo: Brasiliense, 1989.

CERTEAU, Michel de. A invençâa do cotidiano: 1. Artes de Fazer. Petrópolis: Vozes, 1994.

DAMASCENO, Bruna. Governo apresentará 20 projetos do Ceará 2050 no segundo semestre. O Povo, Fortaleza, p, 14, 3 ago. 2019a.

- O desafio de manter a qualidade do serviço de transportes por aplicativos. O Povo, Fortaleza, p. 13, 4 ago. 2019 b.

DOSSE, François. A história em migalhas: dos Annales À Nova História. São Paulo: Ensaio; Campinas: Editora da Universidade Estadual de Campinas, 1992.

FOUCAULT, Michel. A coragem da verdade: o governo de si e dos outros II: curso no Collège de France (1983 - 1984). São Paulo: WMF Martins Fontes, 2011.

FENTRESS, James; WICKHAM, Chris. A memória social: novas perspectivas sobre o passado. Lisboa: Teorema, 1994.

HALBWACHS, Maurice. A memória coletiva. São Paulo: Vértice; Editora Revista dos Tribunais, 1990.

JAPIASSU, Hilton. O sonho transdisciplinar e as razóes da filosofia. Rio de Janeiro: Imago, 2006.

JUCÁ, Gisafran Nazareno Mota. A oralidade dos velhos na polifonia urbana. Fortaleza: Imprensa Universitária, 2002.

KOTHE, Flávio René. Para Ler Benjamin. Rio de Janeiro: Francisco Alves, 1976. . Benjamin \& Adorno: Confrontos. São Paulo: Ática, 1978.

; FERNANDES, Florestan (Org.). Walter Benjamin. São Paulo: Ática, 1985.

KONDER, Leandro. Walter Benjamin: O marxismo da melancolia. Rio de Janeiro: Campus, 1988. 
LEAL Jocélio. De Boa Intenção O "Nordeste" Está Cheio. O Povo, Fortaleza, p. 32, 28 jul. 2019.

LEPETIT, Bernard. Por uma nova história urbana. São Paulo: Edusp, 2001.

LIPOVETSKY, Gilles. A era do vazio: ensaios sobre o individualismo contemporâneo. Barueri: Manole, 2005.

. A felicidade paradoxal: ensaios sobre a sociedade do hiperconsumo. Lisboa: Ediçóes 70, 2014.

. O império do efêmero. São Paulo: Companhia das Letras, 2009.

MOSÉ, Viviane. Nietzsche e a grande política da linguagem. Petrópolis: Vozes, 2018.

MURICY, Katia. Alegorias da dialética: imagem e pensamento em Walter Benjamin. Rio de Janeiro: Relume Dumará, 1999.

NIETZSCHE, Friedrich. Além do bem e do mal: prelúdio de uma filosofia do futuro. Petrópolis: Vozes, 2009.

. O anticristo: maldição ao cristianismo: diritambos de Dionísio. São Paulo: Companhia das Letras, 2007.

PERNISA JUNIOR, Carlos; FURTADO, Fernando Fábio Fiorense; ALVARENGA, Ilton Assunção. (Org.) Walter Benjamin: imagens. Rio de Janeiro: Maud X, 2008.

SELIGMANN-SILVA, Márcio (Org.). Leituras de Walter Benjamin. São Paulo: FAPESP; Annablume, 1999.

\section{Fonte Oral}

OLIVEIRA, Francisco José de Castro [72 anos]. [Dez. 2018]. Entrevistador: Gisafran Nazareno Mota Jucá. Fortaleza, CE. 5 dez. 2018. 
Resumo: Nenhuma paisagem urbana é monolítica, mas polivalente e multifacetada. Ao longo das várias ruas, vários olhares se debruçam sobre as experiências cotidianas expressas nas práticas sociais vivenciadas. $\mathrm{O}$ narrador, nosso guia, o professor Francisco José de Castro Oliveira, nos revela o valor do seu depoimento, uma recordação envolvida na memória social e coletiva. $\mathrm{O}$ panorama projetado sempre é plural, dialético, multifacetado, e as paisagens retidas se apresentam tranquilas ou turbulentas, dependendo do estado de espírito do narrador. As múltiplas revelaçóes do cotidiano urbano se nos afiguram como símbolos de representações sociais projetadas.

Palavras-Chave: Paisagens Urbanas. Memória Individual. Memória Social.

\title{
Individual memory as an expression of social memory: revealing reminiscen- ces of the multiple facets of Fortaleza
}

\begin{abstract}
No urban landscape is monolithic, but multipurpose and multifaceted. Throughout the various streets visited, various views focus on the daily experiences, expressed in the social practices. The narrator, our guide, the professor Francisco José de Castro Oliveira, reveals to us the value of his statement, a remembrance wrapped in social and collective memory. The projected panorama is always plural and dialectical, multifaceted; the landscapes are tranquil or turbulent, depending on the narrator's mood. The multiple revelations of urban daily life can be considered as symbols of projected social representations.
\end{abstract}

Keywords: Urban Landscapes. Individual Memory. Social Memory.

Recebido em 10/08/19

Aprovado em 07/11/19 